\title{
Legal Protection for Consumers Against Buying and Selling Goods Transactions Through Online Shops
}

\begin{tabular}{|c|c|}
\hline \multicolumn{2}{|c|}{$\begin{array}{c}\text { Aditya Migi Prematura } \\
\text { Faculty of Law, Universitas Pekalongan, Pekalongan, Indonesia }\end{array}$} \\
\hline Info Artikel & Abstract \\
\hline \multirow[t]{2}{*}{$\begin{array}{l}\text { Keywords: } \\
\text { Legal protection; Consumer } \\
\text { protection; Online shop. }\end{array}$} & $\begin{array}{l}\text { The development of technology in the era of industrial revolution } 4.0 \\
\text { is very rapid. These developments triggered developments in all } \\
\text { sectors, one of the most affected by the industrial revolution } 4.0 \text { was } \\
\text { the trade sector. In the current era of } 4.0 \text {, trade has begun to develop } \\
\text { from conventional trading that is trading through physical markets or } \\
\text { more often we are familiar with supermarkets, malls, mini markets, } \\
\text { and so forth to trade through online markets or more commonly } \\
\text { known as E-Commerce. This is a fresh wind for consumers because } \\
\text { with the switch of trade through E-commerce, a myriad of } \\
\text { conveniences offered by the E-commerce. The conveniences include } \\
\text { that consumer do not need to leave the house to buy an item, or in } \\
\text { other words a trade transaction can be done anywhere without having } \\
\text { to spend special time to travel to a store or shopping center. Not only } \\
\text { positive things and conveniences caused by this development, but a } \\
\text { myriad of problems that nowadays often occur in online buying and } \\
\text { selling activities. Starting from goods that do not match the } \\
\text { description or information provided by businesses to the delay of } \\
\text { goods that have been promised by businesses, to other problems that } \\
\text { essentially harm the consumer. }\end{array}$ \\
\hline & Abstrak \\
\hline $\begin{array}{l}\text { Kata kunci: } \\
\text { Perlindungan hukum. } \\
\text { Perlindungan konsumen; } \\
\text { Online shop; }\end{array}$ & $\begin{array}{l}\text { Perkembangan teknologi di era revolusi industry } 4.0 \text { sangatlah pesat. } \\
\text { Perkembangan tersebut memicu perkembangan dalam semua sektor, salah } \\
\text { satu sektor yang paling terpengaruh dengan adanya revolusi industry } 4.0 \\
\text { adalah sektor perdagangan. Pada era } 4.0 \text { sekarang ini perdagangan sudah } \\
\text { mulai berkembang dari perdagangan secara konvensional yaitu perdagangan }\end{array}$ \\
\hline $\begin{array}{l}\text { Corresponding Author: } \\
\text { Aditya Migi Prematura, } \\
\text { E-mail: } \\
\text { adityamigi94@gmail.com }\end{array}$ & $\begin{array}{l}\text { dengan melalui pasar fisik atau yang lebih sering kita kenal dengan } \\
\text { supermarket, Mall, pasar swalayan, mini market, dan lain sebagainya ke } \\
\text { perdagangan melalui pasar online atau yang lebih kita kenal dengan E- } \\
\text { Commerce. Hal tersebut merupakan angin segar bagi para konsumen } \\
\text { dikarenakan dengan beralihnya perdagangan melalui E-commerce maka }\end{array}$ \\
\hline P-ISSN: & segudang kemudahan yang ditawarkan dengan adanya E-commerce tersebut. \\
\hline E-ISSN: & $\begin{array}{l}\text { Kemudahan-kemudahan diantaranya yaitu konsumen tidak perlu keluar } \\
\text { rumah untuk membeli suatu barang, atau dengan kata lain transaksi jual beli } \\
\text { dapat dilakukan di mana saja tanpa harus meluangkan waktu khusus untuk } \\
\text { bepergian ke toko atau pusat perbelanjaan. Tidak hanya hal positif dan } \\
\text { kemudahan saja yang ditimbulkan dengan adanya perkembangan ini, tetapi } \\
\text { segudang permasalahan yang sekarang ini sering terjadi dalam kegiatan jual } \\
\text { beli secara online. Mulai dari barang yang tidak sesuai dengan deskripsiatau } \\
\text { keterangan yang diberikan oleh pelaku usaha hingga keterlambatan barang } \\
\text { yang sudah dijanjikan oleh pelaku usaha, hingga permasalahan- } \\
\text { permasalahan lain yang intinya merugikan pihak konsumen. }\end{array}$ \\
\hline
\end{tabular}




\section{Introduction}

Technological developments in the era of the industrial revolution 4.0 triggered changes in the trade sector. The sophistication of today's modern technology and the opening of a global information network that is completely transparent marked by the emergence of the internet, cybernet, or the world wide web (www) which is a technology that allows the rapid transformation of information throughout the virtual world. ${ }^{1}$ The internet, which has been very developed so that it reaches almost all parts of Indonesia, provides various facilities for the people of Indonesia. In the trade sector, the advancement of the internet has triggered a change in habits in buying and selling transactions. Buying and selling used to be done conventionally, where consumers came directly to the shopping center. Now with the development of the internet, consumers no longer need to shop directly at shopping centers but able to shop online via smart phones. With the advancement of the internet and technology, it provides convenience and a positive impact for both business actors and consumers. This kind of information technology business is known as electronic commerce or electronic business. E-commerce (technology commerce), as part of e-business (business conducted using electronic transmission). In general, ecommerce can be defined as all forms of trade/commerce transactions of goods or services (trade of goods and services) using electronic media. ${ }^{2}$

This electronic sale and purchase contract tends to use a legal system that refers to the norms or rules that apply in a country, including in Indonesia. Based on the provisions of the applicable buying and selling law, there are several things that are essential in the buying and selling process, namely regarding the rights and obligations of the perpetrators in carrying out a sale and purchase contract which is confirmed at the time of the sale and purchase agreement as a supporter of the validity of the evidence of a sale and purchase agreement. There are several advantages that can be obtained by using the internet as a trading medium, namely:

a. Advantages for buyers:

1) lowering the selling price of the product;

2) increases the competitiveness of sellers;

3) increase buyer productivity;

4) better information management;

5) reduces the cost and time of procurement of goods;

6) better inventory control.

b. Advantages for sellers:

${ }^{1}$ M. A. Sanusi, 'Transaksi Bisnis Dalam E-Comerce: Studi Tentang Permasalahan Hukum Dan Solusinya', Ius Quia Iustum Law Journal of Islamic University of Indonesia, 16.8 (2001), 10-29 <https://doi.org/doi: https://doi.org/10.20885/iustum.vol8.iss16.art2. p. 10>.

2 Utkarsh K. Mishra and Abhishek Negi, 'Should Trade Remedies Be Eliminated from WTO: A Response to Tania Voon', Journal of Human Rights, Culture and Legal System, 1.3 (2021). 
1) better identification of target customers and market definitions;

2) better cash flow management;

3) increases the opportunity to participate in the procurement of goods or services (tender);

4) improve efficiency;

5) the opportunity to expedite the payment process for goods orders;

6) reduces marketing costs.

With this e-commerce system, a seller (seller) does not have to meet directly (face to face) with buyers (buyers/consumers), in a trade transaction. Transactions can occur only through correspondence via e-mail, telecopy and others. Payments can also be made via the internet. ${ }^{3} \mathrm{~A}$ data message containing an agreement (agreement and contract agreement) can be conveyed by one of the related parties (as the originator) to another party (the recipient, addressee) directly or through a mediator (intermediary) through electronic services such as the internet, extranets, e-mail and more. ${ }^{4}$ According to Bajjaj in his book entitled E-commerce: The cutting edge of business, he mentions a number of advantages (advantages) that can be obtained from e-commerce, including:

a. Time saving;

b. Reducing the possibility of making errors in typing and so on because a standard model has been prepared which is never retyped; and

c. Because business time can be used as efficiently as possible, it is very possible to get more information about the business so as to support the effectiveness and efficiency of a company or business. ${ }^{5}$

However, this online transaction also has some disadvantages. By using online transactions that do not bring together those who have online businesses and direct buyers and also the consumers cannot see the desired goods in real (in their actual form and condition) this can cause problems that are detrimental to buyers in conducting online transactions. Examples are the incompatibility of the promised goods, the inaccuracy of the delivery time of the goods. "Online transaction security factors such as payment security are one of the problems for people who buy goods online". 6

The problems above show that in several respects, transactions in e-commerce are very risky, especially because the consumer has the obligation to make advance payments while he cannot see the truth of the goods ordered or their quality. Payments made electronically, either through bank transfers or, by filling

${ }^{3}$ R Ustadiyanto, Framework E-Commerce (Yogyakarta: PT Andi, 2001).

4 Sanusi.

5 P Nindyo, 'Revolusi Dunia Bisnis Indonesia Melalui E-Commerce Dan E-Bussines: Bagaimana Solusi Hukumnya', Ius Quia Iustum Law Journal of Islamic University of Indonesia, 16.8 (2001), 15 <https:/ / doi.org/https:// doi.org/10.20885/iustum.vol8.iss16.art1>.

6 Siti Rahma Novikasari, Duc Quang Ly, and Kerry Gershaneck, 'Taxing Micro, Small and Medium Enterprises in Yogyakarta: Regulation and Compliance', Bestuur, 9.1 (2021), 43-52. 
out credit card numbers on the internet, open up opportunities for civil and criminal fraud to occur, while there is no exact guarantee that the ordered goods have been delivered in accordance with the order.7 In Law Number 19 of 2016 concerning Amendments to Law Number 11 of 2008 concerning Information and Electronic Transactions, it is stated that electronic transactions are legal acts carried out using computers, computer networks or other electronic media. In electronic buying and selling transactions, as well as ordinary buying and selling transactions carried out in the real world, they are carried out by the parties involved, although in this electronic buying and selling the parties do not meet each other directly, but communicate via the internet. ${ }^{8}$

In buying and selling electronically, the parties involved include:

a. Seller or merchant as business actor;

b. Buyers or consumers;

c. Bank as channeling party of funds from buyers or consumers to sellers or business actors/merchant;

d. Provider as internet access service provider.

Similar research on consumer protection in buying and selling transactions through e-commerce has also been carried out by several academics, for example the journal written by I Putu Erick Sanjaya Putra, et al which was published in 2019 in the Journal of Legal Analogies, Faculty of Law, Warmadewa University Denpasar- Bali with the title Legal Protection for Consumers in Buying and Selling Goods Through E-Commerce. In his research, I Putu Erick Sanjaya Putra discusses legal protection for consumers in buying and selling goods through ecommerce which is limited to legal arrangements for buying and selling goods through e-commerce and legal protection for consumers who experience losses due to buying and selling e-commerce goods. Where the results of the study state that consumer protection against losses in buying and selling transactions through E-commerce is contained in Article 28 paragraph 1 of the ITE Law. ${ }^{9}$

Based on the above, the authors in this study are interested in studying the legal protection of consumers who buy goods through online shops in terms of Law Number 8 of 1999 concerning Consumer Protection and also Law Number 19 of 2016 concerning Amendments to Law Number 112008 concerning Information and Electronic Transactions.

\section{Methods}

\footnotetext{
${ }^{7}$ Moh. Iqra Syabani Korompot, Sholahuddin Al-Fatih, and David Pradhan, 'The Principle of Equality Before the Law in Indonesian Corruption Case: Is It Relevant?', Journal of Human Rights, Culture and Legal System, 1.3 (2021).

${ }^{8}$ Sanusi.

${ }^{9}$ Mas Pungky, Hendra Wijaya, and Mohammad Zulfikar Ali, 'Legislation Impediments in Reorganising Government Bodies in Indonesia', Jurnal Bestuur, 9.1 (2021), 1-12.
} 
This study uses a normative legal research method, which means collecting materials from various laws and regulations and using some written literature. Legal material in this analysis can be divided into two, namely primary data and secondary data. Primary legal materials, namely legal materials that have strong rules by forcing every human being or society, which consist of statutory rules, namely: Code of Civil law, Law Number 8 of 1999 concerning Consumer Protection, and Law Number 19 of 2016 concerning Amendments to Law Number 11 of 2008 concerning Information and Electronic Transactions. Secondary Legal Materials, are legal data that have ties to primary legal data that can help analyze understandings and explain primary legal data, including: Law books resulting from previous analysis, mass media and electronic results. ${ }^{10}$

\section{Results and Discussion}

\section{Consumer Protection in Online Selling (E-Commerce) According to Law Number 8 of 1999 concerning Consumer Protection}

The Consumer Protection Law (UUPK) does not specifically regulate buying and selling transactions carried out via electronic media or online, but the UUPK regulates buying and selling transactions between business actors and consumers in general. Even though consumers make purchases through online shops, this UUPK can still guarantee legal protection for consumers because online shops are only a means or place used by business actors to offer goods or services as well as offline stores in general. ${ }^{11}$

In general, e-commerce can be defined as all forms of trade / commerce transactions of goods or services (trade of goods and services) using electronic media that are connected online known as the internet, commerce activities are part of business activities. ${ }^{12}$

Article 4 of the Consumer Protection Law states that consumer rights are:

a. the right to comfort, security, and safety in consuming goods and/or services;

b. the right to choose goods and/or services and to obtain such goods and/or services in accordance with the exchange rate and the promised conditions and guarantees;

c. the right to correct, clear and honest information regarding the conditions and guarantees of goods and/or services;

d. the right to have their opinions and complaints heard on the goods and/or services used;

${ }^{10}$ Peter Mahmud Marzuki, Penelitian Hukum (Jakarta: Prenada Media Group, 2017).

${ }^{11}$ Elizabeth Putri Sutrisno and Wasis Sugandha, 'Kendala Pemerintah Dalam Melindungi Hak Atas Keamanan Bagi Konsumen Kuliner Makanan Berbahan Baku Daging Anjing', Jurnal Discretie, 1.1 (2020), 1-8.

${ }_{12}$ M Fuady, Hukum Kontrak: Dari Sudut Pandang Hukum Bisnis, Buku Pertama (Jakarta: PT Citra Aditya Bakti, 2001). 
e. the right to obtain proper advocacy, protection, and efforts to resolve consumer protection disputes;

f. the right to receive consumer guidance and education;

g. the right to be treated or served correctly and honestly and nondiscriminatory;

$h$. the right to obtain compensation, compensation and/or replacement, if the goods and/or services received are not in accordance with the agreement or not properly;

i. rights regulated in the provisions of other laws and regulations.

On the other hand, the obligations for business actors (in this case are online sellers), according to Article 7 of the Consumer Protection Law are:

a. have good intentions in carrying out their business activities;

b. provide correct, clear and honest information regarding the condition and guarantee of goods and/or services as well as provide an explanation of the use, repair and maintenance;

c. treat or serve consumers correctly and honestly and non-discriminatory;

d. guarantee the quality of goods and/or services produced and/or traded based on the provisions of the applicable quality standards of goods and/or services;

e. provide opportunities for consumers to test, and/or try certain goods and/or services as well as provide guarantees and/or guarantees for goods manufactured and/or traded;

f. provide compensation, compensation and/or compensation for losses resulting from the use, use and utilization of traded goods and/or services;

g. provide compensation, compensation and/or replacement if the goods and/or services received or utilized are not in accordance with the agreement.

The connection with the protection of consumers who buy goods through online shops, can be seen in Article 8 paragraph (1) letter $\mathrm{f}$ of the Consumer Protection Law which prohibits business actors from trading goods/services that are not in accordance with the promises stated in labels, etiquette, information, advertisement or promotion of the sale of said goods and/or services. Based on the article, the discrepancy between the specifications of the goods received by the consumer with the goods listed in the advertisement/photo of the offer of goods is a form of violation for business actors in trading goods, according to Article 4 letter $\mathrm{h}$ of the Consumer Protection Act, consumers are entitled to compensation, compensation and / 
or replacement if the goods and / or services received are not in accordance with the agreement or not as they should be. ${ }^{13}$

Meanwhile, the business actor himself pursuant to Article 7 letter $g$ of the Consumer Protection Law is obliged to provide compensation, compensation and/or replacement if the goods and/or services received or utilized are not in accordance with the agreement. If a business actor violates the prohibition on trading in goods/services that are not in accordance with the promises stated in the label, etiquette, description, advertisement or promotion of the sale of said goods and/or services, the business actor can be punished based on Article 62 paragraph (1) of the Consumer Protection Law which reads:

"Business actors violating the provisions as referred to in Article 8, Article 9, Article 10, Article 13 paragraph (2), Article 15, Article 17 paragraph (1) letter $a$, letter $b$, letter $c$, letter e, paragraph (2) and Article 18 shall be sentenced to a maximum imprisonment of 5 (five) years or a maximum fine of Rp. 2 billion."

\section{Protection of Law Number 19 of 2016 concerning Amendments to Law Number 11 of 2008 concerning Information and Electronic Transactions, Against Consumers Who Purchase Goods Online}

As happens in real-world commerce, the primary legal basis for ecommerce transactions is contracts. The contract here concerns business to business and business to consumer. Online contracts in internet transactions have several variations including: ${ }^{14}$

a. Electronic network development and arrangement contract (website design and development contract)

b. Contracts via chat and video conferencing

c. Procurement contract for payment by credit card

d. Contract by email.

The practice of e-commerce that is developing so fast as we feel today is unfortunately not accompanied by the development of a legal basis that specifically regulates e-commerce so that it can be used as a guide for the creation of legal certainty. Apart from the above, there are several advantages of e-commerce for the benefit of organizations, individuals and society. The advantage for the organization is that with e-commerce it can expand the

${ }^{13}$ Resti Dian Luthviati and Suviwat Jenvitchuwong, 'Implementation of Halal Product Assurance in the Pharmaceutical Sector in Indonesia', Journal of Human Rights, Culture and Legal System, 1.3 (2021).

${ }^{14}$ Nandang Sutrisno, 'Cyberlaw: Problem Dan Prospek Pengaturan Aktivitas Internet', Jurnal $\begin{array}{lllll}\text { Hukum IUS QUIA } & \text { IUSTUM, } & \text { 30-41 }\end{array}$ <https://doi.org/10.20885/iustum.vol8.iss16.art3>. 
marketing place for national and international markets. Buying and selling through online media should follow existing regulations, fulfill the elements of buying and selling in the Civil Code. ${ }^{15}$

One of the government's efforts to create a safe and reliable transaction system is by issuing Law Number 19 of 2016 concerning Amendments to Law Number 11 of 2008 concerning Information and Electronic Transactions. Transactions of buying and selling goods through online media have at least two parties who are legal subjects who have legal relationships with each other, these parties include the seller or business actor and the buyer or consumer. The existence of the buyer as a consumer provides a reason in buying and selling online must also heed the rights of consumers as regulated in the consumer protection law. ${ }^{16}$

Online transactions through internet media can use website facilities, use electronic mail, can also use electronic data interchange (EDI) or other facilities for transactions. One type of online buying and selling transactions that is currently widely used is through Instagram, Facebook and online buying and selling shops such as Zalora, Tokopedia, Lazada, shopee, etc. Every trade transaction has risks and problems, one of the problems faced is when a default occurs so that there is a violation of consumer rights. One of the problems that often occurs in online buying and selling transactions is where the goods purchased by consumers do not match what is stated in the description/photo of the offer provided by the business actor. ${ }^{17}$

In Law Number 19 of 2016 concerning Amendments to Law Number 11 of 2008 concerning Information and Electronic Transactions, the article imposed is Article 28 paragraph (1), which reads as follows: (1) Everyone intentionally and without rights spreads news lying and misleading which results in consumer losses in Electronic Transactions. The criminal threat from this article is imprisonment for a maximum of 6 (six) years and/or a fine of a maximum of Rp. 1 billion (Article 45 paragraph (2) of the ITE Law). For proof, you can use electronic evidence and/or printouts as an extension of evidence as referred to in Article 5 paragraph (2) of Law Number 19 of 2016 concerning Amendments to Law Number 11 of 2008 concerning Information and Electronic Transactions, in addition to other conventional evidence in accordance with the Book Criminal Procedure Law (KUHAP). ${ }^{18}$

${ }^{15}$ Hendry Julian Noor, Kardiansyah Afkar, and Henning Glaser, 'Application of Sanctions Against State Administrative Officials Failing to Implement Administrative Court Decisions', Bestuur, 9.1 (2021), 53-67.

${ }_{16}$ Pungky, Wijaya, and Ali.

${ }^{17}$ Novikasari, Ly, and Gershaneck.

${ }^{18}$ Loresta Cahyaning Lintang, Adriano Martufi, and J.W. Ouwerker, 'The Alternative Concepts of Blasphemy Law in Indonesia: Legal Comparison with Ireland and Canada', Bestuur, 9.1 (2021), $13-25$. 
Article 5 of Law Number 19 of 2016 concerning Amendments to Law Number 11 of 2008 concerning Information and Electronic Transactions:

1) Electronic Information and/or Electronic Documents and/or their printed results are valid legal evidence

2) Electronic Information and/or Electronic Documents and/or their printed results as referred to in paragraph (1) is an extension of valid evidence in accordance with the applicable procedural law in Indonesia.

Buying and selling online in principle is the same as buying and selling factually in general. The law on consumer protection related to online buying and selling transactions, as previously explained, is no different from the law that applies in real buying and selling transactions. The difference is only in the use of internet facilities or other telecommunication facilities.

\section{IV.Conclusion}

The protection of consumers who make buying and selling transactions through online shops (E-commerce) is guaranteed enough by the existence of Law Number 8 of 1999 concerning Consumer Protection, especially in the provisions of Article 4 of the UUPK regulates the rights of consumers, one of which is the right to get compensation, compensation and/or replacement, if the goods and/or services received are not in accordance with the agreement or not properly. The UUPK also regulates the obligations of business actors in Article 7 letter $g$ that business actors are obliged to provide compensation, compensation and/or replacement if the goods and/or services received or used are not in accordance with the agreement. If a business actor violates the provisions of the UUPK, then the business actor can be punished based on Article 62 paragraph (1) of the Consumer Protection Law.

\section{References}

Fuady, M, Hukum Kontrak: Dari Sudut Pandang Hukum Bisnis, Buku Pertama (Jakarta: PT Citra Aditya Bakti, 2001)

Korompot, Moh. Iqra Syabani, Sholahuddin Al-Fatih, and David Pradhan, 'The Principle of Equality Before the Law in Indonesian Corruption Case: Is It 
Relevant?', Journal of Human Rights, Culture and Legal System, 1.3 (2021)

Lintang, Loresta Cahyaning, Adriano Martufi, and J.W. Ouwerker, 'The Alternative Concepts of Blasphemy Law in Indonesia: Legal Comparison with Ireland and Canada', Bestuur, 9.1 (2021), 13-25

Luthviati, Resti Dian, and Suviwat Jenvitchuwong, 'Implementation of Halal Product Assurance in the Pharmaceutical Sector in Indonesia', Journal of Human Rights, Culture and Legal System, 1.3 (2021)

Marzuki, Peter Mahmud, Penelitian Hukum (Jakarta: Prenada Media Group, 2017) Mishra, Utkarsh K., and Abhishek Negi, 'Should Trade Remedies Be Eliminated from WTO: A Response to Tania Voon', Journal of Human Rights, Culture and Legal System, 1.3 (2021)

Nindyo, P, 'Revolusi Dunia Bisnis Indonesia Melalui E-Commerce Dan EBussines: Bagaimana Solusi Hukumnya', Ius Quia Iustum Law Journal of $\begin{array}{lllll}\text { Islamic University of Indonesia, } 16.8 \quad \text { (2001), } & 15\end{array}$ <https://doi.org/https:// doi.org/10.20885/iustum.vol8.iss16.art1>

Noor, Hendry Julian, Kardiansyah Afkar, and Henning Glaser, 'Application of Sanctions Against State Administrative Officials Failing to Implement Administrative Court Decisions', Bestuur, 9.1 (2021), 53-67

Novikasari, Siti Rahma, Duc Quang Ly, and Kerry Gershaneck, 'Taxing Micro, Small and Medium Enterprises in Yogyakarta: Regulation and Compliance', Bestuur, 9.1 (2021), 43-52

Pungky, Mas, Hendra Wijaya, and Mohammad Zulfikar Ali, 'Legislation Impediments in Reorganising Government Bodies in Indonesia', Jurnal Bestuur, 9.1 (2021), 1-12

Sanusi, M. A., 'Transaksi Bisnis Dalam E-Comerce: Studi Tentang Permasalahan Hukum Dan Solusinya', Ius Quia Iustum Law Journal of Islamic University of Indonesia, $\quad 16.8 \quad$ (2001), $\quad 10-29 \quad<$ https://doi.org/doi: https://doi.org/10.20885/iustum.vol8.iss16.art2. p. 10>

Sutrisno, Elizabeth Putri, and Wasis Sugandha, 'Kendala Pemerintah Dalam Melindungi Hak Atas Keamanan Bagi Konsumen Kuliner Makanan Berbahan Baku Daging Anjing', Jurnal Discretie, 1.1 (2020), 1-8

Sutrisno, Nandang, 'Cyberlaw: Problem Dan Prospek Pengaturan Aktivitas Internet', Jurnal Hukum IUS QUIA IUSTUM, 8.16 (2001), 30-41 <https:// doi.org/10.20885/iustum.vol8.iss16.art3>

Ustadiyanto, R, Framework E-Commerce (Yogyakarta: PT Andi, 2001) 